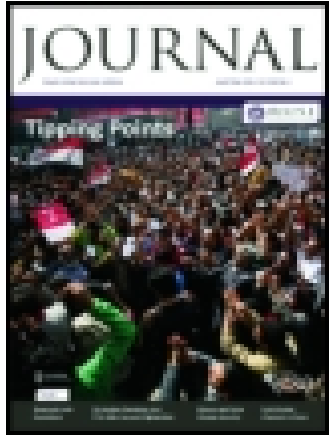

Royal United Services Institution. Journal

\title{
What can the Volunteers of England do to Render Themselves Fit to Take the Field?
}

\author{
Colonel R. Harrison C.B., C.M.G., R.E., \&c.
}

To cite this article: Colonel R. Harrison C.B., C.M.G., R.E., \&c. (1885) What can the Volunteers of England do to Render Themselves Fit to Take the Field?, Royal United Services Institution. Journal, 29:132, 1087-1112, DOI: 10.1080/03071848509417999

To link to this article: http://dx.doi.org/10.1080/03071848509417999

\section{Published online: 11 Sep 2009.}

Submit your article to this journal $₫$

Џ Article views: 2

Q View related articles $\square$ 
Friday, July 10, 1885

General G. ERSKINE, Member of Council, in the Chair.

\title{
WHAT CAN THE VOLUNTEERS OF ENGLAND DO TO RENDER THEMSELVES FIT TO TAKE THE FIELD?
}

\author{
By Colonel R. Harrisox, C.B., C.Ir.G., R.E., \&c.
}

The Cinsmaras : Ladies and gentlemen, it is nith great regret that I hare to announce that Lord Wemgss is prevented from being here this afternoon, and from taking the chair as he had intended to do, in consequence of urgent business in the Ilouse of Lords. I am sure it will be a matter of rery great disappointment to all who hare attended to hear this paper, that Lord Wemyss is not here to gire us the benefit of his adrice and criticism.

Tire circumstances of the last few months have once more stirred up the feeling that the force chiefly relied on for the defence of England - the Volunteers-are not as ready to take the field as they might be. But no one, as far as I know, has yet attempted to detail what requires to be done, or how to do it. 1

'The object of this paper is to endeavour to throw some light on this subject.

The process of turning a peace army-i.e., a number of men, horses, guns, and other stores-scattered about where most convenient for purposes of subsistence or custody into a war army concentrated at certain strntegical points is called mobilization.

Every nation in Europe except England has I believe thought this matter out. It has settled what portion of its arailable peace army shall be made a morable one capable of taking the field, aud what part shall be equipped for garrison duty only; it has made elaborato tables showing what has to be done at each military district, and at each place of concentration as soon as the order to mobilize is issued; it has prepared all the necessary ciothing, equipment, and transport, or, at all erents, has arranged how and where to lay hands on them; and it has made up its mind how to obtain the required number of Staff and Departmental Officers.

All this might be done for England and her Colonies withont spending a penny of the taxpasers' money. All that is required is that a few of the able Staff Officers, of whom the country possesses so many, shall be told off to do the task.

1 The paper by Lieut. General Sir E. Iramley on "The Tolunteers in Time of Need," in the "Nineteenth Century" for March, was discussed for three dass, and the discussion is reported in full in No. CXXX of the Journal.-Ev. 
But it requires time. It is the sort of work that cannot be done in a hurrs and in the excitement immediately preceding a war.

This process of preparation cannot be done by the Volunteers, so I will say no more about it than to express a hopo that it may be undertaken before it is too late. Unless it be done beforo an enemy sets foot on our shores, all that may bo brought about by individual effort to fit the Volunteers for mar will be sinply thrown away.

But I will turn at once to the question, What is it that the Volunteers can do to make themselves more reads to take the field than they are now? and the answer I give is that they can do two things -they can proride themselves with personal equipment, and they can obtain instruction in the art of war.

No doubt a large proportion of the Volunteer Force will be employed in what is called garrison daty-that is, they will act on the pure defensire in the neighbourhood of their native towns and villages. Some, howerer, will bo in a position to leare their homes for an indefinite period, and these latter will be available to be organized into war battalions, and to form a portion of the moring army. But whether employed in garrisons or in the field one and all require a personal equipment, and it wonld be better for simplicity of supply if all were equipped in a similar manner.

I have used the word personal equipment, and I hare done so adrisedly, because when wo talk of equipment generally we mean all the paraphernalia required to enable any body of men and horses to take the field. This includes the equipment of the individual soldier, the equipment of the regiment, and the equipment of the brigade or the Division. It is the equipment of tho individual soldier \$hich is our present concern. What then is an English Volunteer likely to require in the field; what is the use of cach article, and how is it to be carried? I will take them in the following order :First, the clothes in wear, then the arms and accoutrements; and, lastly, any other articles thought necessary.

In settling the cut and material of a coat, as in crerything else, success is onls attained by working on some fised principle. Now, the principles to bear in mind when we are considering what should bo the dress of the soldier are, I think, these-taken in the order of their importance-its fitncss for war purposes, its fitness for garrison duty, and its appearance.

In considering the dress of the Volunteers we are relieved from one of the difficulties attending the question as it affects the regular Arms, inasmuch as the Voluntecrs are not intended for service else. were than in the British Isles, whereas the regulars are liable to serve in erery climate under the san : and we have to deal only with the linited question, what is the best dress for war and peace for a soldier in Fngland.

Bearing in mind the first principle laid down-the fitness of a soldier's dress for war-I cannot but think that a great mistake is made when an inferior material, to wear a short time, is issued instead of a good material to wear $\dot{a}$ little longer. This is done no. doubt for the eake of appearance, because.a new coat, especially. 
when men don't own the clothes they wear, and consequently are not over-careful of them, looks better than an old one. But when an army goes on a campaign, and when food and ammunition are rightly sent to the front before anything else, it is often months before men can be supplied with new clothes, and the shoddy coats and trousers go to pieces, and leare the wretched soldiers with nothing but rags to protect them against wet and cold.

What the colour of the Volunteers' dress should be is too big a question to deal with here. A good deal has been written and spoken on this subject, and opinions are much divided. If there were, as there used to be, two descriptions of infantry-heary and lightI should say that the heary infantry should have one colour and the light infantry another, which would be a great help to Commanders and Staff in the field. Bat when, as is the case now, all infantry are equipped in the same nanner, and have similar duties to perform (the only difference between them being that what are called rifle regiments have a different drill with the rifle), I do not think it matters a jot whether so-called rifle regiments hare a dress of a different colour to others or not.

As to the shape of the dress, I should say, speaking generally, that we cannot do better than stick to the Austrian tanic which wo have adopted the last few years, and to which the eye has got accustomed. But in matters of detail this dress requires, I think, a good deal of alteration to render it fit for war.

Let me go a little more into detail. I think that a suitable dress for the Volunteers of Fngland wonld be as follows :-

A tunic of good material fitting the back and waist, with a pleat on each side of the breast buttons so that there shall be amplo play in front, an upright collar to protect the neck, loose sleeves fastened at the wrist by a strap; cartridge holders to hold ten cartridges. stitched on the breast so that they shall not interfere with the accoutrements, breast pockets inside, and the badge and number of the regiment $a$ little below the point of the shoulders so that it can be seen from the side. A waistcoat with sleeves to be worn under the tunic in cold weather. Pantaloons made to fit at the knee, but quite loose from the knee upwards, with pockets at tho sides.

Leather gaiters fastened by string loops.

Shooting boots which can be tipped and heeled before a campaign. A felt lat, looped up at one side, and ornamented by a feather.

$\Lambda$ flannel shirt.

Hand-knitted socks.

A pair of glores or mitts.

A flannel belt.

A pair of braces or a thin leather belt.

The adrantages which; I think, the abore-named dress possesses over the dress which is now generally worn by Volunteers, can only bo tested in war, or in circumstances as like war as possible. You must hare the hot march on a dusty, road in the midst of a crowd of your fellow-men; you must have the heary shower of rain to endure; the ford to cross; the ploughed field to pass over; and you must 
birouac under a hedge; or by the side of a hastils made trench; and, lastly, you must. know what it is for the fate of your company, or your battalion, to depend upon the rapidity with which jon can firo a few well-aimed rounds, beforo you can say whether the dress you wear is one really suitable for war or not.

Bat to resume. Our next consideration of the articles of personal equipment of the Volunteer are his arms and accoutrements.

In the case of these, just is in the case of dress, the important point to bear in mind is fitness for war. A soldier's rifle must not only. be able to carry a bullet with extreme accuracy to a distance almost out of sight, but it must be of such a weight that it can be carried easily in addition to other necessary articles by a man of arerage strengtb, and it must be simple in construction, so that it shall not be put out of order by the rough nsage that it is liable to in the field. The ammunition must be as light as possible consistent with being really serricenble.

Thile on this subject let me say a word regarding the change that is now being talked about in the Jlartini-Henry ammunition. Already tho ammunition that wo carly is heavier than that of anj other European nation, and when we bear in mind that every ounce of extra weiglit carried by the soldier decreases his marching and fighting powers, and overs pound of extra weight carricd in the transport wagons decreases their power of bringing np supplies, we should, beforo making any change, consider most carefully whether tho adrantage gained is sufficient to counterbalance the disadvantage that would arise should any extra weight be thereby imposed on the marching arms.

The question of bayonet or sword bajonet should be considered in connection with that of the intrenching tool, and nothing should be adopted withont careful trial under circumstances as nearly like war as possible. It must be remembered that anything in the shape of a spade lianging to a soldier's waist is a great impediment to him when marching, and my owit impression is that tho best thing for tho Volunteer to carry in the field rould bo a trowel fitted into a caso which also holds the bayonet. The trowel can be constructed to cut brushrood ats rell as to make a kitchen, or trench for a birouac, or riflepit for a sentry. When it is required to make regular fieldworks, the intrenching tools that are carried in regimental transport can always be made arailable.

The scabbard for the bayonet should be of Ieather, as at present, and the whole thing, viz., case, trowel, and bajonet, can be so made as to be casier carried and less of an impediment to the soldier than the sword bayonet with steel scabbard now carried by the Royal Artillery. Ammunition poncbes must be sufficiently large to hold 100 rounds if required. The usual number of ronuds carried in the field is sixty in the two pouches and ten in the cartridge holders on the coat.

The waistbelt most be considered in conjunction with the rest of the accoutrements. By itself it cannot support the weight that a soldier has to carry when he is completely dressed and equipped for 


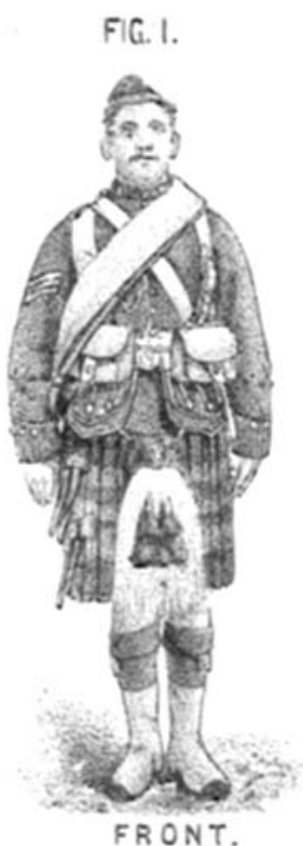

FIG. 4 .
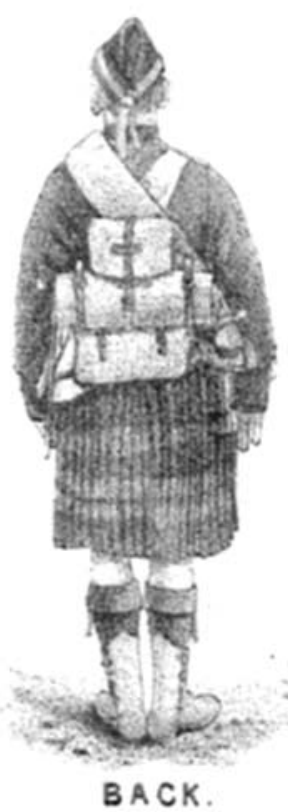

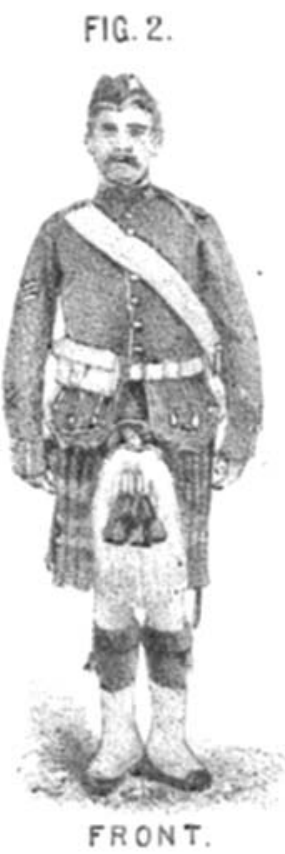

FiG. 5.

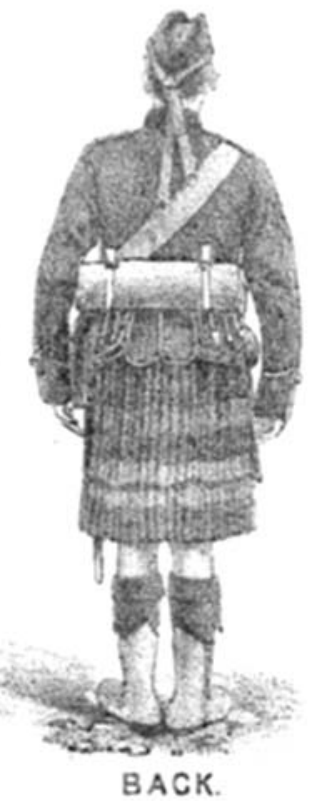

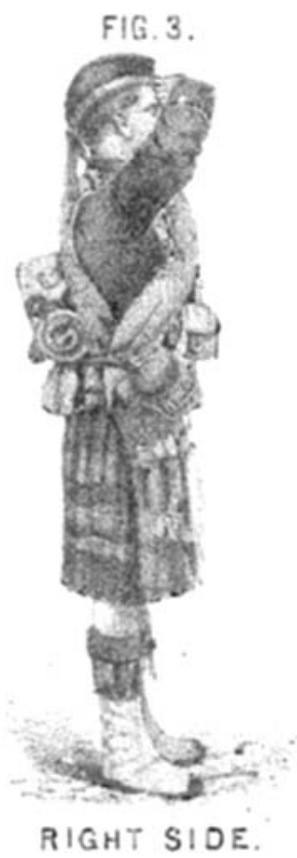

FIG. 6.

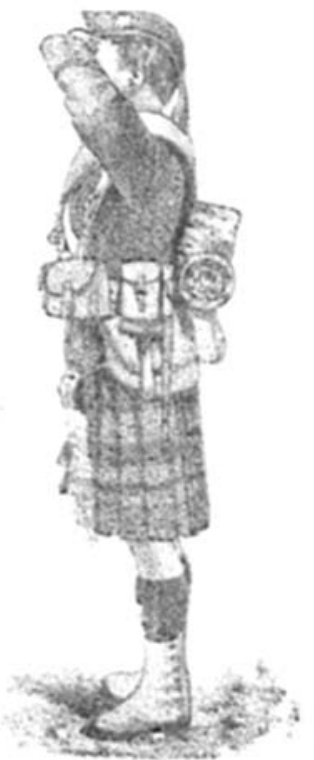

LEFT SIDE 
rar, and consequently it has to be supported by braces. The braces, as used by the infantry soldier in the regular Army, are so arranged that they carry the ralise behind and support the ammunition pouches in front. In the latest pattern valise equipment they can also be used to sapport the belt when the valise is not carried, the grent coat rolled and strapped to the waistbelt behind acting as a counterpoise to the ammunition pouches. When it is borne in mind that the knap. sack or valise is nerer carried by the soldier on the march in modern war, there seems no reason why our Volunteers should be burdened with one, and I would suggest their being provided only with waistbelt, ammunition pouches, and braces, as supplied to the regular infantry in the latest pattern ralise equipment.

I would, howerer, provide every Volunteer with a waterproof bag, similar to the one used by sailors, which will hold the articles of kit. in excess of what the men carry on their backs. This bag would be left at the place of assembly of the regiment when the men marched away to take the field. It would be useful to them for the days or weeks that they remained there, and it would enable them to start awry with eversthing they had ou clean and in good condition. The bag is fastened at the top by a piece of cord, and can be padlocked if thought adrisable. It can easily be carried a short distance on a man's shoulder.

The best water-bottle that I have seen is a galranized iron one, enamelled inside, aud covered with feIt outside. It has a cork stopper. It should be made to hold $1 \frac{1}{4}$ pints. If larger it is too heavy for a man to carry on the march. It should be made with a strap, to suspend it from the shoulder, this strap being useful also to enable it to be filled from a well or piver. It should hare, moreover, a cloth strap to fasten it to the waistbelt, and thus keep it steady.

The haversack should be sufficiently large to hold. three dajs' biscuit or bread. It should be waterproof outside, and have an inner coating of linen, which can be taken out and washed from time to time. It should be carried by a linen or canvas strap orer the shoulder.

An oil bottle will be required for the rifle. I should like to seo this as well as the necessary cleaning kit, \&c., carried in a small pan in the butt of the rifle, as is done frequently in sporting rifles. In default of this, it must be carried in oue of the pouches.

Lastly, we will consider the other articles which. it is thought a Volunteer should possess to fit him for war.

The first of these is the great coat, which should be considered in conjunction with the cape. The real object of a soldier's great coat is to keep him warm, while that of the cape is to keep him dry. An old soldier doing a day's march on a wet day will prefer not to wear his greal coat, for he knows that if he does it will add immensely to his labour, and before long the wet will penetrate it, and the result will be that when he arrives at his journey's end he will not have a dry thing to pat on. But a soldier under the same circumstances would be glad to wear his cape if it were made sufficiently long to protect his accontrements, because it would keep him fairly dry and would not hnmper his movements. 
The remarks that I have alrcady made about material apply with eren greater force to the great coat than they do to the tunic.

I am of opinion that tho Volunteer shonld be prorided with a great cont of really good woollen material, not too thick, and not coming down below the knce, because thickness and length mean weight. It should hare a roll collar which can be turned up when required. It should hare straps at the wrists to euable the sleeres to be tightened there, and the skirts should be mado to batton back, and he should be provided with a cape to be rorn eitler with or without the cont. The cape to be waterproofed, and to reach down as far as the waist. The cape should, I think, be carried by the Tolunteer on all parades, rolled and strapped to the rraistbelt behind, where it lies in the hollow of the back quite out of the was. On marching order parades when the great coat is fastened to the waistbelt, the cape might be carried "en banderole" over tho left shonlder, where it would be in a position for immediate use whenerer required.

The Volunteers cannot do better than adopt the old pattern infantry canteen, which is made of just suffeient size to carry a man's messing when regetables are added. It will cook for two men in tho field, so that a man and his comrade have a spare canteen for their tea or rater.

If the Voluntecrs are provided with the hat I have mentioned, which is light and comfortable, they would not require a forage cap. But they should hare a woollen night cap for field service, which could be used when convenient in garrisons.

A field "dressing" is supplied to every man before starting for active serrice. This should be issaed to Volunteers when they assemble prerious to taking the field.

Erery Volunteer should be provided with a small book in which should be recorded his description, serrice, clothing, pajments, dic., in fact, erersthing concerning his life as a soldier.

The remaining articles which I think bo would require, and which could all be carried casily in his waterproof bag, are as follows :-

A second pair of pants.

A sccond tanic.

A pair of strong shoes.

A pair of canras gaiters to fit orer the shoes.

$A$ hold-all fitted as a house-wife, and containing a fork, spoon, and comb.

A clasp knife and tin opener with lanyard.

Cleaning kit and materials, carried in a small linen bag.

2 pairs of socks.

2 flannel shirts.

2 towels.

A small T'estament and Praycr Book, and

4 silk pocket handkerchiefs, which can be used as nech handkerchicfs when required.

When a Voluntecr takes the field, the following articles only will probably be taken by him. All the remainder of his kit should be 
packed away in his waterproof bag and left at the place of assembly of the regiment or wherever else may be ordered at the time.

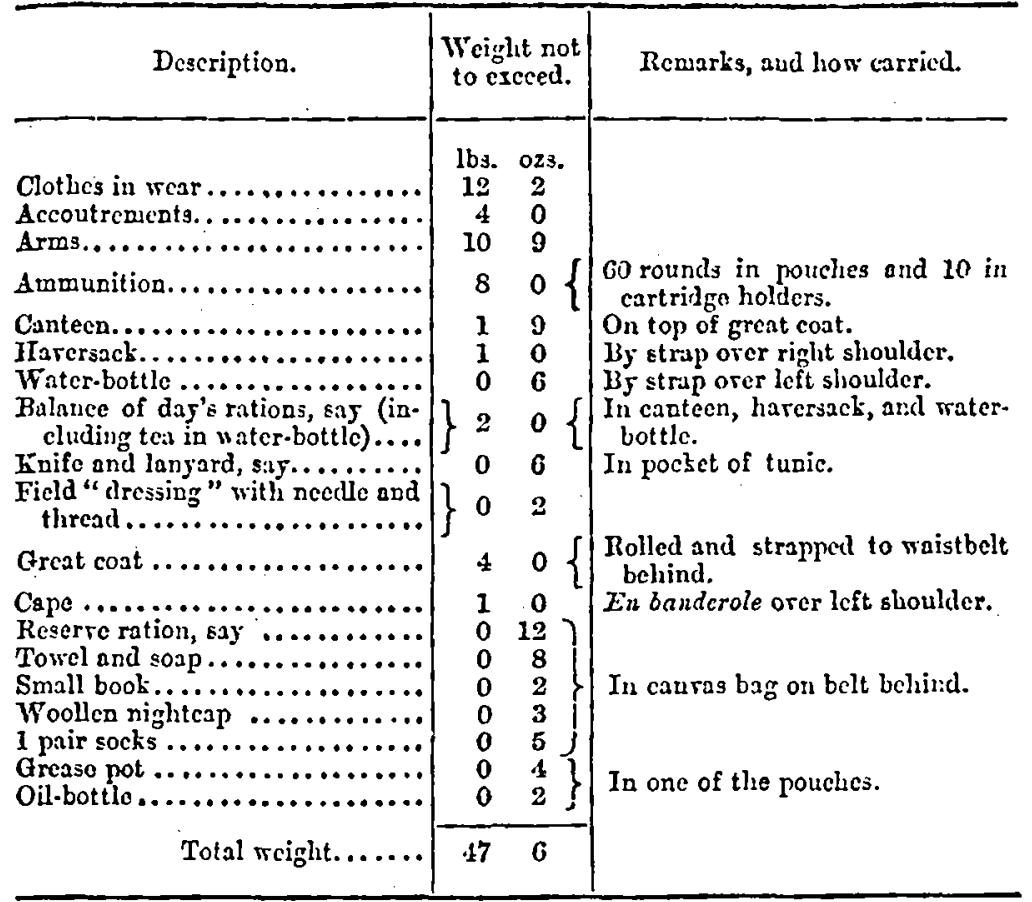

Erergthing taken in the abore list should be as good as new in the matter of wear.

Additional rations will oceasionally hare to be taken. When this is the case they will probably consist of biscuit and cheese, and they must be carried in the haversack.

I have now, in as much detail as is probably necessary, gone through the rarious articles of personal equipment which I think are required to be in possession of the Volunteers of England to render them fit to take the field. But the question may arise how are all these things to be provided, and who will bear the cost; and I don't feel it right to las down my pen until I havo given my answer at least to these questions. It has been, I understand, for some years the castom for the Commanding Officers of the Metropolitan Voluntecrs to meet together and discuss certain questions conceruing the corps thes command; and it seems to me that this custom has only got to bo extended a little to crente a Central Association,?which slall consider not only equipment but other matters affecting the Volunteers 
throughout the conntry. No action would of course be taien on the deliberations until the sanction of H.R.H. the Field.Marshal Com. manding-in-Chief and the Secretary of State for War had been obtained. The funds to maintain such an Association could be provided by contribations from all corps who were willing to join, and who, in right of their subscription, should be allowed to send a representative to ali meetings of the central body.

The business of the Association in the matter of equipment would be to consider what articles should be provided for Volunteers, and what should be the nature of each article. The reisult of these deliberations might be circulated to all the Volunteer Corps who had joined the Association.

I am aware that it is the opinion of some, if not mans, members of the Volunteer Force that the War Department should proride them with all necessary equipment, if not clothes. With this opinion I am at rariance. The position originally triken up by the Volunteers was, I believe, that they were entirely independent of Government aid. 'The feeling that prompted them was that every man, in return for his rights of citizenship, owed some personal service to the State; and that while the poor man could enter the ranks of the Regralar Army or the Militia, the moll-to-do citizen -could enrol himself as a Volunteer, or at least could find funds to enable some one to do so in his stead.

I am aware of the patriotism that influences most members of the existing Volunteer Corps, and I know of the large sacrifices in timo and money made by many. Nevertheless, I cannot help expressing it as my opinion that as a matter of principle the Fiorce should never have accepted Gorernment aid except when embodied, and except for the provision of arms and ammunition and drill-grounds.

There is, I believe, no question that when the Volunteer movement was first started the amount of money received was salficient for all needs. I presume that although individuals may give more now the subscriptions are not so general as they used to be. Perhaps the reason of this is that the need is not made known. Whatever may be the cause, at all events I rould urge a general staternent being circulated in districts where the headquarters of Volunteer Corps are established before any further help is asked for from the Gorernment. Should any of those appealed to shrink from their obvious duty as citizens, it mar be well to remind them that the ranks of the Mlilitia are far from being full, and that should the Volunteers fall off is: numbers or efficiency it is more than probable that soover or later the ballot will hare to be applied in order to obtain men for the firstnamed force. If the appeals fail to obtain the necessary funds, there will be nothing for it but to go to the Government and say, "We have done all we can; if you wish us to be really efficient you must give us a grant to enable us to provide ourselves with personal equipment."

Bat in any case each Volunteer corps, ander the guidance of the Central Association, should be held responsible for obtaining a personal equipment sach as I have described; the actual pattern and the manuer of purchase being left to local choice. 
I have already stated that the Volunteers have it in their power to do two things to make themselves more rendy to take the field than they are at present. They can provide themselves with 'personal equipment and they can obtain instruction in the art of war-and I have described in some detail what their personal equipment should consist of.

Before dealing with the second part of the subject-the instraction for war-it may be well to say rery briefly what equipment other than personal will have to be provided for such of the Volunteers as may be required to march with the actire army. This equipment, as preriously stated, is divided into that of the regiment, and that of the brigade or Division. All of it must be provided at a time of need by the Government of the country, and the more carefally the Govern. ment consider what are the stores which are absolutely necessary, and where they can best be obtained when wanted, the cheaper and easicr will be the eventual process of "mobilization."

It need hardly be said that a battalion. of infantry mobilized for war is a very different thing from a peace battalion such as we are accustomed to see at our parades and sham fights. The latter is merely an assemblage of some $500 \mathrm{men}$, while the former consists of 1,096 men of all ranks, as well as 70 horses and 15 carts and wagons. Of the rumber of men in a war battalion, it is assumed that when the necessary depôt is formed at the base of operations, 1,000 men will still be available to march forward against the enemy, and for this nnmber regimental transport has to be provided. The description of transport that an army takes into the field raries with the nature of the country in which the campaign is about to take place. Sometimes it consists of wagons, sometimes of carts, sometimes of pack animals, and sometimes even of boats. Whaterer its description, however, the same. system holds with regard to the sapplies and stores which it carries. Thus ammnnition is taken in special carts, or on special mules to the extent of 30 rounds a man. A fixed number of intrenching tools are taken on a cart designed for tho purpose, or on mules. One wagon, or a certain number of pack animals, are detailed for headquarters, and the same for every two companies. Two magons are detailed to carry with the battalion the daily Commissariat supplies, and three wagons the tents if they are ordered to accompany the force.

All wagons, and carts, and batches of mnles haro certain special articles of equipment told off to them, which they carry independently of any other stores that they may be required to conrey with the battalion. The headquarter wagon and the company wagons carry between them one day's reserve rations, a blanket per man, the regulated amount of baggago for Officers, and such fow books and special tools as it is thonght are absolutely necessary in the field.

Similarly, when pack takes the place of wheel transport, a certain number of mules or ponies are detailed to headquarters, and a certain number to each company to take the samo stores as rould bo contained in the wagons.

Each corps in an army, if properly equipped, should have 
sufficient regimental transport to take with it similar stores to those which are above named as being taken with a battalion of infantry. Thus a battery of artillery, besides its guns and its special stores of ammunition, tools, books, $\mathbb{d} c$.; should take a blanket and a reservo ration per man, and should bo provided with a separate cart to carry the daily supply of Commissariat rations. : The same with the engincers, in addition to their pontoons and telegraph stores, and their special supply of tools and materials. Tho samo with tho Conmissariat Corps, in addition to their bakery and butchery coluunus; and the same with the Medical Staff Corps, in addition to their field hospital and bearer equipment.

The equipment of a brigade or Division consists of that of tho various corps of which it is composed, together with sach extra equipment as tho probable necessities of the campaign suggest.

It would perhaps be sufticient for a campaign in England, where it is presumed the railways would be available to a certain extent for purposes of supply, if the colnmns that followed the mering army contained only a reservo of ammunition to supplement the regimental reserve, and a reserve of two or threo days' rations.

But it is unnecessary to pursue this subject any further here. It was introduced to show how necessary previous preparation is, if n conntry wishes to be in a position to make use of the material she possesses to create a ficld army.

We will now turu to that portion of the subject which moro immediately concerns the Voluntecrs themselres, and proceed to the inquiry how they can obtain instraction in the art of war.

The answer that naturally suggests itself is, by books-and ono wonders why, in these days of much writing and rapid printing, no text-book of instruction for Volunteers has yet appeared. Perhaps the reason is that no one knows how much to extract and how much to omit fron the numerous books that hare been published in Fingland on the subject of the training of infantry.

I venture to think that it would make the task of preparing a text. book an casier one if the object of military training were lept constantly in view in its compilation-and if eversthing were omitted that did not conduce to that object.

Evidently the primary object of all military training should be to prepare men for war-and, as the time that Volunteers can gire to this training is necessarily limited, it would probably be well if tho whole of the time that they can giro ap to drill were deroted to the primary object.

All the circnmstances of war may be comprised under three heads, viz.: the march, the livouac, and the battle. In each of theso circamstances there are two tactical formations, which are technically called "orders," i.e., the close order and the extended order. Thus on the march the troops forming the main body are in what is called colnmn of route, or close order, while those detailed for the protection of tho force are in extended order. In the bivouac the soldiers by their camp fires are in close order, while the camp guards and outposts are 
in extended order, and in the battle the fighting line whether in attack or defenco is in extended order, while tho reserves are in close order.

It is frequently strated that a good deal of drill is neccssary, not as a preliminary instrnction for field morements, but simply as a means by which cliscipline shall be taught. No ono doubts the necessity for discipline in an army. But many think that it may be learned in the home, in the school, and in the workshop, as effectirely as in the recrnits' squad. Whether this be so or not it is hardly to be denied that it can be acquired by a rell-educated middle-class man who devotes himself from motives of patriotism to the profession of arms with greater facility than by the average agricultural labourer who dons the soldier's coat as a means whereby ho may carn his daily bread-and I argue that even if drill which has for its object only the teaching of disciplino and rendering a man what is called smart is considered necessary when the rustic from the plongh has to bo turned into a soldier of the line, it is not an essential in tho case of the Volunteer; all that he requires boing the drill necessary to trein him for war.

The conclusion arriced at is that the Voluntecr can obtain instraction in tho art of war first by the preparation of a text-book extracted from the authorized books of instraction; secondly, by practising carefully in the field the manourres that the text-book contains; and thirdly, by a regulation that no ono shall bo considered efficient until ho has passed through a prescribed conrse of practical training.

$I$ do not propose to describe more in detail than $I$ have donc already what the text-book should contain. Bat I think that it should bo as short and simple as possible, and that while it laid down absolute orders for drill movements, it should contain such plain rules for tactical mancurres that no essential dirergence should be possible when two or moro battalions practised them together. The book might be divided as follows :- Part I. The Instruction of the Volnnteer Recinuit. Part II. Tho Instruction of the Voluntecr Soldier. Part III. MIiscellancous.

Part I would comprise all the necessary instruction in marching; shooting, fc., to enable a Volunteer to tako lis place in tho ranks.

Part II would be the school of tho company, and would contain all that the great majurity of Volunteers would be required to know; and

Part III would contain miscellancous instruction, such as orders for wearing dress and equipment, orders for railwas travelling, details of the annual course of drills, instructions for inspections and reviews, instructions for funernls, $d c$, and perhaps the few essential movements in the drill of a battalion and a brigade.

If a good book were prepared on the lines aboro laid down, it would go rers far with an intelligent bods like the Volunteers to prepare them for practical instruction in the art of war.

The practical instruction itsclf would be the conclusion of their training. It should be given at every opportanity, on ground prorided by the Gorernment, to men who hare gone through the whole of the drills contained in Parts I and II. 
This subject conld be continued at much greater length than has hitherto been attempted, by citing examples of the practical training which it has been suggested shonld be the invariable wind-up of the Volunteers' book-stady and barrack-drill.

But knoring as I do that each example requires careful and continnous study if it is to be useful or even amusing, I lave decided that it will be best not to introduce one in this paper.

I have now shortly, bat I hope clearly, answered the question with which I started, and explained what in my opinion is required to make the Volunteers fit to take the field.

I hare, moreover, indicated how far the business can be done by the Volunteers themselres, and what must be left to be carried out by the Government.

Whether the Government will do their share of the work or not I cannot say, but I feel sure that the Volunteers, who have so nobly initiated themselves as the bulwark of defence of their country, and who have stuck so zealonsly and persistently to the business, will, as far as they are able, complete tho work they have began: and if what I hare said helps in however small a way to bring about such a result, I shall be well content.

Colonel Loxisd LIE Hate, late R.E. : My friend Colonel Harrison has approached this important question from more than one point of riew, but $I$ am glad he has not drelt too long upon that much-trodden platform, which I may call the greatcoat and equipment platform, of which we hare heard a great deal lately. Doubtless greatcoats and equipment are of importance to tho Tolunteer force collectirely and indiriduall, but at the same time it is simply a side issue, because we may be perfectly certain that if the nation were convinced that the Tolunteer force, by which I mean the 250,000 efieients, were absolutely efficient in erery other respect, it would nerer stop at the simple matter of supplying them with greatcoats and equipment. If a man has spent nineteen shillings and eleren pence three farthings on in object which he thinks worth a sorereign, he does not think twice orer the last farthing. But there appesrs to bo some little scepticism in the nind of the nstion as to what the efficiency of the Volunteer force is. Coloncl Harrison has boldly stated, in the title of his lecture, that he does not consider the Toluntecr force able to take their place in the field, and he has also indicated what that place is; how times hare changed since the Voluntecr force ras originally organized, and how at the present day the part that they would take in the field is changed, and is now twofold; for when the Volunteer force was first organized it was looked upon as a reserre intended to hold garrisons and relicre the rest of the regular Army, but now-a.days, as Colonel liarrison has stated, we shall find not only a large force of Folunteers in reserve, but a large number of them in the front line, where they will hare to mect the first shock of inrasion, and the question which has to be considered is, Do we honestly and really beliere that these 250,000 men are able to meet the first shock of invasion in the front line? Against what? No Power who attempted the inrasion of this country would send any one on that desperate and hazardous mission but the flower of her troops, and we may be perfectly sure that if Germany sent a force against this country she would send three or four Army Corps of picked men, picked soldiers. Bearing in mind, then, the imperfect training of our 250,000 Volunteess; bearing in mind their indifferent shooting; bearing in mind the absence of continuity of habits of discipline; bearing in mind the composition of the corps of Tolunteer Officers, and remembering whom they would bo opposed to, zan any one conscicntiously say that these 250,000 men as a mass are ready at this moment to take their place in the front line to resist an inrasion? Speaking on this point, a Yolunteer Officer said to me, "But that does not matter. In six weeks I could 
get my battalion as good as any battalion in the line." But we sliall not hare the six weeks; we cannot rely on the six weeks; we must hare our Volunteers, if ther are to be ready at all, to be ready at the rery moment of attack. Now in answer to the question I hare put I quite agree with Colonel Harrison in sajing that they are not ready. He makes an assumption, howerer, from which I differ entirely, that the Volunteers can, by any roluntary effort of their own, make them. selres fit for the post in the front line. I am talking now of the whole 250,000 Voluntecrs. Iet us think for a moment what are the opportunities which they hare, with the time at their disposal, for making themselres fit. We hare the Saturday afternoon drills, which I dare say in the quiet seclusion of the rural distriets may be rery raluable, but any Commanding Officer who lires near a big town where he has to drill his battalion knows what a small amount of instruction he can put into the time at his disposal amidst the shouting and shrieking of the lowling mob around him. Then with regard to the shooting. Hare our Volunteers any means whaterer at their disposal of getting practice sufficient to enable. them to cope with the men I hare indicated as landing on these shores-these Germans, who are trained to shoot at 1,000 or 1,200 Jards or more-what facilities hare our. Volunteers of learuing to shoot in order to meet on an equal footing men who are trained in that way? We hare these so-called "caups of instruction," of which we hear a great deal, and in the hospitality of which many of us hare partaken. To an outside observer these Yolunteer camps may appear to be so organized that the men come when they like, stay as long as. they like, and go away when they like, thus rendering any systematic instruction during the time the battalion is there absolutely impossible. And now I come to speak of what may appear to be a delicate subject, but $I$. hare no delicacs in touching upon it at all, the subject of the constitution of the corps of Folunteer. Officers. I can only speak of them from what I know of them, of the many. friends $I$ hare among them. They aro men who harre been noble and generous enough to open their purses widely, and to gire up all the time at their disposal for the benefit of their country. Thes, perhaps, liked to take to soldiering, but it was in fulfilment of a duty that they took their place at the head of what was really a great national morement. They are men who, like myself, hare other occupations, they hare their duties in their professions, they have their duties to their families; they hare to look after the question of home supplies; and, therefore, you cannot expect a Folunteer Oflicer to gire up more of his time to his military pursuits than that which is left from his other, and, to him, far more importanl duties. And yet it is an axiom among military men that the weaker, the less-trained jour rank and file are, if you rant those men to hold their own, and to be well disciplined in the field, the stronger rust be your corps of Offeers. Nerer was that shomn more clearer than cluring the war of 1870 , when hundreds and thousands of brare Frenchmen were put into the field ready to fight to the last, but with the trained Oflicer elcment. wanting. Therefore we must hare a force of Opicers of somewhat better training than the body of the Officers of the 250,000 men. Now, gentlemen, is there any chance of these 250,000 men giring more, either of their time or money, as has been suggested, to the further progress of the Volunteer morement?. Remember, the only may in which you can possibly train Reserre forees for the ficld is to do it in the may it is done abrond. Let us cast aside for once our excessire insular conceit and military solf-confidence, and beliere that after all foreigners do know something about military training and military affairs. We shall find that they bring their Reserve forces for a series of jears, for a month or sir weeks at a time, together, and that they officer them most carcfully, and then they are able to keep up a well-trained and thoroughly disciplined body of reserre troops, ready if need be to act in the front line. Until we hare our Reserre forces going in this way into camps for screral wecks at a time for four or firc Jears in succession, and properly officered, we shall nerer be able to hare Reserre troops of the required standard. - But can you expect 250,000 men to do that?. I emplatically sas you cannot. You cannot ask these 250,000 men to meet the demands on their timo which are required, and I do not sce why you should ask them for more money; but is it not possible that out of that great force of 250,000 men, bearing in mind

roL. XxIX. 4. $\mathrm{C}$ 
the double duty which, as Colonel Irarrison indicated, Folunteers rould bare to perform, the Reserre duty which thes hare at present, and their position in the front line, would it not be possible to further set the prineiple of roluntecring and ask whether among that 250,000 men there is one-tenth part of them-a corps of 25,000 men-who would be willing simply to gire up more time to their country? Would it not be possible to get among the soung men of Fngland 25,000 men who will say-" Ies, we will engage for the next four or fire years regularly for a month or six rreeks in the jear to come into a camp and undergo the sererest training, in order to make ourselves fit for the defence of the country as 'Tolun. tcers of the Line" "? Then extend that to the Offeers. Go among the regular Oficers and say, "Will any of you rolunteer to belong to that corps?" Jiany men would if the expenses were decreased, and then you would be ablo to offecr your corps with as strong an infusion of the Regular element as of the Volunteer element. I imagine if a corps of that class were formed, jou would haro within a rery few years a corps of 25,000 rery fairly trained men to which it would be a man's greatest pride to belong, and thes would be the " Volunteers of the Line." It would not interfere in the slightest degree with the reserve. Voluntecrs, who would be as they are now, and the Goremment would be able to lay its hand upon $a$ body of 25,000 English Toluntecrs who would be also 25,000 English trained soldiers. Gentlemen, I ask jou whether the time las not come when the Gorernment of this country should not make a fresh bargain with the Volunteer force. When it was first originated the Tolunteers came forward to the Gorernment and said, "Here, gratuitously, we gire you our scrrices," and the Gorernment accepted them. By degrees the serrant found his ecrices becoming more raluable, and he comes to his master and sass, "Now you must pay me in kind and in money." The master agreed for a time. The serrant became still more effeient, and norr master and serrant are at a deadlock. The serrant sajs he can become more eflicient yet, but he wants more payment, and the master says, "In the first place I cannot afford to pay all jou $250,000 \mathrm{men}$, and in the next place should 1 accept you on your terms you, must do me more duty." "Well, let us striko a fresh bargain.. Iet the Gorcrnment eay to the Voluntecrs, or to the 25,000 men, "We merely want Jour time; wo will reliere you of erery singlo expense, wo will cren pay jou while jou are in camp, because we know what a cheap force you will be when wo have really trained you." . Lict us make this distinction betrreen the "Volunteers of the Line" and the "Voluntecrs of the Resorre," instead of trying to deal with this luge, almost ucmanagcable, question of equipping and training 250,000 Voluntecr soldiers, let us begin by dealing with 25,000 only. We hare heard from the lips of a dead hero that re ought not to study minor tactics, but read Plutarch's "Lires," because there we shall find how men died for their country. We hare got 250,000 men in the Tolunteers who are ready to die for their country. Now we want to get from that number the pick of them, the 25,000 men who are not merely ready to dic for their country, but ready to spend their lires in its serrice also.

Colonel Darres, Assistant-Adjutant and Quartermaster-Gencral Southern Diri: sion: I am sure not only the Volunteers but probably a great many Officers of the regular drmy, who tate in great interest in the Yolunteer morement, will be decply indebted to my friend Colonel Ifamison for the interesting paper he has read to us, and for bringing this important question forward. I hope, as I belong to the latter class, that. I may be allowed to say a few words. Sir Ceorge Willis has begged me to express his rery great regret that he is not able to attend on this occasion to take part in the discussion of a subject in which he is so deeply interested as the question of the organization of Voluntecrs. WVith regard to the transport, it is a matter on which $I$ should like to say a few rords. At the beginning of this jear, Sir George Willis, being desirable that, if possible, tho Voluntecrs in the Southern District should be quite independent as far as transport mas conccrned, desired me to issuc a menorandum pointing out that it was rery desirable that they should be perfectly independent of the Gorcrnment in regard to transport in the case of mobilization, because, if they mere mobilized, probably all. the military transport would be taken by the regular Army, and they would be obliged to scramblo for what they could get with the Militis-for anj extra trans- 
port not required for the $A$ rmy. It then goes on to point out what he considered might be necessary, and loped it might be obtained with little or no espense to the Tolunteers. It pointed out that if a battalion was about 800 strong, it would probably want three ammunition carts, and it suggested that these might be got from butchers, bakers, and others who had corered earts, which would make very good ammunition carts with two horses, one looked in front, which might be used as a pack animal to carry the ammunition where the carts could not go. There should ulso be another cart with one horse for the intrenching tools, and eight wogons to carry the baggage and provisions, each with two horses; and for this purpose it suggested that carriers' rans might be used. This I dare say scems a rery small number of horses, but the transport would not hare to more any great distance, and only on good roals such as we hare in this country. Therefore, they need not be horsed in the same proportion.in which we find ragons are horsed for field services in other countries. With regard to ambulance, it suggested that they might utilize omnibuses and cabs; and it also suggested to the Commanding Officers of the Southern District that they might ask owners of this sort of transport if they would not show the sane patriotism as was shown by the other members of the Toluntecr force, and come formard and furnish their wagons at a regulated price, and that they should be asked to come out in the case of camps of instruction and, on a few occasions, for marches. If this was done, Sir George thought that the War Oflice might rery properly be asked to allow the orreers and drirers of these transports to become members and earn the capitation grant; and also that if the Volunteers organized this transport it would be quite fair to ask the War Ofice to supply camp equipments-tools, greatcoats, water-bottles, sc., for the Volunteers. Nearly all the Commanding Officers in the Southern District acquieseed in it and promised to do their best to mork it out, especially Colonel Frerett, Coloncl Stuart, and Sir William Humphery. Afterwards it was considered that it should be brought formard, if possible, by the Offecrs commanding the Voluntecr corps generally, as they mere much in farour of it. Sir George Willis asked some of them to put forward a scheme, which they did, and I will just read a few notes which $I$ hare taken from that scheme. Colonel Stuart foresaw littlo diffeulty in organizing such a transport as mas suggested by Sir George Willis. $\Delta t$ the same time he thought it would be rather difficult to get carts for ammunition; \&c., strong cnough for the Tork. Colonel Ererett immediately asked permission to organize this transport. IIe proposed that there should be a payment made of $5 s$. a day for each horse emplored, and he rade out that the expense rould come to 54l. 10s. for the three days which he proposed to use them during his encampment. I do not know whether be is here to-day or not, but first of all he has made an error in figures of $11 \mathrm{l}$, and in the next place ho asked for 58 horses instead of 29 ; therefore, according to Sir Georre Willis's scheme, if he paid $5 s$. for a horse, it would only come to 211 . 15s., and if there was a capitation of 30 s. for cach man, that would be $22 l$. 10s. Sir Georgo Willis is particularly anxious that in any scheme for transport, rery little expense should be thrown on to the Volunteer corps. II wishes to get pcople to come forward and furnish the transport at a moderate rate: Sir William Ifumphery las taken it up still more beenly. Ife immediately asked permission to organize and use this transport in his camp at Ovington Park, Win. chester, on the 25 th of this month. He asked also whether a eapitation grant could bo giren, but of courso it was needless to say that it could not be giren this year. I am happy to say, howerer, that Sir William Fumphery, with his usunl liberality, has determined that he will have the transport this Jear at his onn cxpense, and therefore at his camp he intends to have all this transport for his battalion. I am quite sure that any gentleman who takes an interest in this subject $J_{1 a s}$ only to go down there, and Sir William Humphery will be pleased to show what lie has donc. It has been taken up so much by. Commanding Officers of tho Southern District, that I am sanguine enough to hope that next year all the corps in the district will hare got transport, and with rery little expense to the Voluntecrs. I slionld like to say one word on the question of drill. Colonel Harrison says something about drill, and he rather led one to beliere that there was too much drill, and that Volunteers could mako themsclres efficient with little or no drill. There I entirely differ from him. I think they must hare a certain amount of $4 \mathrm{c} 2$ 
drill like other men, though they do not mant the same drill as the ordinary soldier. If he alludes to marching past, I think Officers mas waste too mucl time in trying to make their men march past rell; but it is imperatirely necessary that they should hare a certain amount of close-order drill, and very careful drill in extended. order. If anjbody thinks men can fight in extended order without rery carcful. drill, he is rery much mistaken. I maintain that we want more drill in this than. they used to lase in the old days, when sou might bare a number of inefficient men in the battalion who did not know their drill, and they would be carried along with the othcrs who did know their drill; but now each individual man must bo drilled, and if you do not tesch cach man to keep his proper distance and direction. in extended order if they are fighting with a largo body of men, I am sure they will get into hopeless confusion. Thereforo I think they want a good deal of drill. Thes want a good deal of drill, too, in outpost duty, and $I$ hope that the Commanding Officers of Voluntecrs will turn their attention to this rery important matter, which has not been taken up. rery much at present. I lope that no mischierous doctrine will get abroad that people now-a-dass do not requiro drill becalse we fight in extended order.

Colonel RIDGTAY : The subject of the present paper by Colonel IIarrison purports to be confined wholly to "What the Voluntecrs of England can do to render themselres fit to take the Ficld;" therefore; it is entircly beside the question for us to enter into tho matter of their equipment or of anj proposed changes, whether local or otherwise, in their dress. That disposes at once of the greatcont and water-bottle question. What the Tolunteers themselres can do to render the force effectire in the ficld appears to me to be a matter of sufficient importance in itself to cause us in the present discussion to confine oursclres to that point. The action a Tolunteer can tale is trio-fold : first as a soldier, and secondly as a cirilian. As a soldicr, his dnty is plain and simple. It is not to propose or inrent according to his own crotehets new systems of dress, new systems of equipnent, or new systems of drill and discipline, but simply to learn and do his duty as a soldier and to obey the orders of his superior Officers. With reference to the remarks of the last speater, I may be permitted to point out that Colonel Harrison's expressions did. not refer to a considerable amount of drill being unnecessary; but that it was unnecessary to hare such a large amount of discipline, which drill was mainly intended to produce. On the other hand, it does secm to me that it is the great ospiration, as well as the duty of the Volunteer, to acquire strict habits of. discipline, and in that as well as in crery other way to make himself, as far as possible, as like the regular Service as can be. Eren in his equipment and drill and headgear ho must seek to make himself efficient in the Regulation Articles, and I doubt rery much whether it wonld be for his adrantage that be should have a soft hat looped up at one side and ornamented with a featlier, unless it should be decided by the authorities that this was the: best leadgcar for the regular Serrice also. The time has gone by when the Yolunteer wished to dress in fancy gear. He is desirous now simply to do his duty, and he is willing to do that. duty without stint of labour or zeal; but I think the line of what is to be expected from him should be drawn at the point where it would be necessary for men such as the Toluntecrs are now composed of-riz., working men, to put their hands in their pockets to ekc out the bare capitation grant. I. am sure that in all branches. of the Serrice it will be found that where the sopitation grant is from farourable circumstances found sufficient, there the Voluntecr Serrice is efficient, and that where the capitation grant is not sufficient-for all demands, there it will to a certain degree pine and languish unless it is supplemented by other means. Fothing, huwercr, can be more certain than the fact, that no reliance ean now be placed upon roluntary contributions; these hare entirely gone by. And upon this: point I fcel bound to insist, because local support and action appear to be the most salient point in Colonel Harrison's remarks. IIe secms to think we should go back to the time (which is in my recollection) when rolunteering was a matter of prirate subscription and amateur soldiering, and when Officers and eren the Adjutant were clected by the men. I remember well a country lanjer, a rery excellent man in prirate life, being selected as an Adjutant, and the men selected their own clothing and their own form of reapon, and organized matters rery much in their onn way. 
In the present day this is not the model of what ought to be; the most prosperous, the largest, and most eflicient corps are not in any way of a pedantic character, but are simply found working according to the lines of the regular Serrice, and endearouring to show themselres in drill, in discipline, in personnel, and in material as much like the regular Service as they possibly can. Nor as to the other point, the way in which a Yolunteer can as a cirilion aid in rendering the force capable of raking the ficld. Although as a soldier ho is precluded from teaching the authorities how to improre his orn equipment or drill, he has, in his cirilian capacity, the opportunity of influencing public opinion, and the action of Parliament in order to induce a much more liberal treatment of the Volunteers in matters of finance, und a much easier treatment of them in regard to nany minor details. And while the Volunteer has the freedom of the civilian to act in this way, ho also lns the adrantage, to a certain degree, of military information and experience to guide his action, from his acquaintance with militars requirements and of the changes of opinion among civilians on military matters. He knows well, for instanec, that the bugbear of the Bilitia ballot is simply a bugbear, and is aware that perhaps the most important means whereby Volunteers may be fitted to take the field, and a large increase of that force as well as of the Militia may be ob. tained, is to prerent any more annual Aets of Parliament suspending the Silitin ballot. If the DIilitia Ballot Act were allowed to take its course, the Volunteer ranks would be immediately filled with men doubly interested in fitting themselves for ser. rice, while it rould also secure the filling up of the ranks of the Militia by ballot. But at the best, the Yolunteer, whether as cirilian or soldier, ean do but little more than he does with his present means to cnable himself to take the field. The Gorernment can of course do a great deal more, and it is for them to consider what the is to take the field with, and how he is to kcep it. 'The subject deserres to be considered as something more than one of Volunteer infantry only. There is no zealous and honest artillery Officer of the regular Serrice who will not say that the brigades of Voluntecr artillery are perfectl 5 fit to man our forts and coast batteries, and to do thoroughly good servico as trained artillerymen. As far as the artillery Volunteers are concerned, they lare been, by their organization, their zeal, and the peculiar nature of their drill, enabled to become more perfect than might have been espected from auriliary soldiers. It is not exactly the same with the Tolunteer

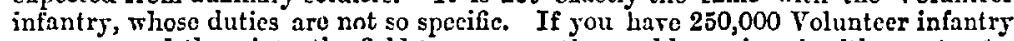
5ou may send them into the field to-morrow, thoroughly equipped with greatconts, rater bottles, and all the paraphernalia which jou choose to eet down in an article as showing what they onght to be fitted with, but if you send those men into the field witlout a proper proportion of caralry and field artillery, transport, and com. missariat, you may just as well keep them at home. Ilowerer much a Tolunteer may do to render himself fit to take the field, it will be useless, unless the caralry and field artillery of our regular Serrice are rery largely increased. It would seam, therefore, if this be the case, that it be the duty of the Gorernment to fit them in this respect, for it cannot be the act of the Tolunteers themselres. In the meantime, so far as the Volunteers can fit themselves by their own action for taking the field thes are progressing rery safisfactorily; and the only means by which ther can be expected to increase the pace at which they are now going will be by increasing the capitation grant where required.

Major the Hon. Scotr NAPIER: I consider that, as at present constituted, the Volunteer force, although an excellent school for training and discipline, a lojal and generously constituted force, is absolutely and utterly incompetert to carry out what General Ifamley and sereral other gentlemen have allotted to it-that is to fay, the defence of our coust against organized inrosion. How can anjbody in his senses, after examining the question coolly, beliere that theso 200,000 men would be forthcoming in time of need? How can we believe that regiments recruited from dockyards and arsenals, telegraph, railwaj officials, and post-office oflicials will suddenly be liberated to go into the field and desert their employment? 'Sueh disorganiza. tion is impossible to $\mathrm{my}$ mind. I think a Saturday afternoon, at a quarter before six o'clock, is, perhaps, the only time when such an idea could be realized. Now, as regards the subject of equipment, I think it is one of the most important subjects in connection with the soldier, for on serrice a man is absolutely lelpless if he has 


\section{WHAT CAN THE VOLUNTEERS DO TO RENDER}

not got a proper means for carrging his ammunition and accoutrements. At tho same time $I$ think it would be utter wastc of money and an unnecessary maste of energy to go into the question of cquipping an arms, a large proportion of which is not to be relied on for effeient service. Again allowing the possibility of mobilizing the Volunteers as an organized body, are they, taking them as a bodr, the men with whom you rould confront the veterans of the German Army? This is another absurdity which ought to bo banished from any calculation as regards the defence of this country. Not a word would I like to say against the Folunteers; they aredoing their best, and they are doing useful work. It is a lojal, conserratire, and manly institution, and long may it lire and prosper! But were I a military authority, making $\mathrm{m}$ calculation of the force at my disposal, I should not count on any one regiment that $I$ know of in the Tolunteer force as a complete unit. I should merely count on so much mixed material haring been created, which might be mado use of in ease of ballot for the Jilitia, or in case of a general conseription. So far as that goes, the Volunteer morement and its system of training are excellent in their way. When Colonel Harrison sars: "Let us consider what the Yoluntece can do for himself," I say that he is willing to do more than be is allowed to do. He is rery ready to shoot; there are hundreds of Folunteers who hare been ready to shoot all through last summer, when the Wormwood Serubs ranges were closed. Thes are rery ready to drill. There is no proper place in London for them to drill in. Colonel Harrison talks about the Gorernment supplying Toluntecrs with open grourd to drill on. He may not be aware that 90 per cent. of the drilling done by the Folunteers is done under corcr and by gaslight, for thero are only dorh hours arailable for Volunteers during winter. Colonel IIrarrison should drawa distinction betreen a man being paid for his serrices, and a man being given facilities for carrying out scrrices that he offers gratuitously. Colonel Harrison infers that it. would be contrary to the spirit of the Folunteer morement rere Foluntecrs to accept money for accoutrements and arms. This morning, a Voluntecr, one of the best shots in England, came to me, and said he would be rery glad to shoot for the Queen's Prize, but he was an artizan, and he could not afford to buy a pair of regimental trousers, required by regulation. A brother Tolunteer immediately lent. him a pair. This shows that there are men who are willing to gire services and time, but who are not able to pay for their necessaries and equipment. I consider that the ascoitrements should be supplied gratuitously by the Gorernment, if not the uniform; that erery facility should be giren to the Voluntcer to practise with his rifle, and to drill, and then rou might perhaps say, "What will the Volunteci" do for himisclf?" Until then the question is, "What will the Gorernment do for the Volunteer?" I think the best way in which we can reulize the number of Toluntcers on whom we could really lay our hands in the time of war, and with whom we could confront the invader, whether French or German, rould be for the Gorernment to offer an additional capitation grant for those men who are prepared to sign a contract, binding themselres to appear when called upon to do garrison duty, and also to attain certain higher standards of efleiency in shooting and drill. Then, if that extra capitation was granted, 20 per cent. of the present number might be made thoroughly eflicient, and you would be able. to realize your force by grouping these reliable men in companies, equippel, and organizing separately from the rest of their corps. I think it rould be an inridious thing to hare two separate Yolunteer forces, it would not be popular; but iet there be one or two companies in the regiment, composed of men of the same regiment, who bare bound them. selres to turn out efficient for a certain number of years, who hare passed the first class in shooting, who are prepared to sacrifice themselres for the sake of their country, then we should hnow a great deal more than we do know now. I must apologize for the imperfect way in which $I$ hare giren rent to $\mathrm{mJ}$ feclings on this question, but haring lad four years' experience of the Volunteers $I$ do not think I should ect my faith in the Volunteer force as it now appears on paper. I beliere jou might really get a dozen regiments that would turn out very well, but it would be impossible to count upon the great majority.

Colonel Irope, t.C.: I find myself obliged to differ from almost ereryonefrom Colonel IIarrison and ererybody elśc-cscept Colonel Ridgway; and beforo I touch on any other point I wish to express my difference with Colonel Lonsdalo 
Hale in the strongest possible manner. It is perhaps hardly a case for ex tzno disce omnes, and my experience is limited, more or less, to the men I hare commanded, and $I$ may possibly be more fortunate in those $I$ have commanded; but all $I$ can say is, that I command the largest corps of any kind in the whole Metropolis, namely, the City of London Artillery of $\mathbf{1 6}$ batteries; and that corps $Y$.unhesitatingly state is, as a matler of fact, ready and fit to take the field to-morror. When I say "take the field," we cannot take the field becanse we have no guns to take the field with, but we are ready and fit to go to work if they gire us guns - we are ready to man the coast batteries, and tho men are thoroughly efficient gunners in erery sense of the word. Many of my own commissioned Officers haro had 10,12 , or 15 years' serrice, and they are in erery respect ns good as the noncommissioned offecrs of the Royal Artillers. There are many gentlemen present to whom I am not known, therefore I may mention that $I$ was a year in the Crimea-a great part of the timo under artillery fire, and I know what that means. I say that my men-and I think I can also speak of the 2nd and 3rd Middlesex Artillery-are ready and fit to-morrow to defend the coast with any guns that may be giren to them to defend the coast with. It is true there are no guns in the country-but that is not the fault of the Volunteers, and that is not the fault of the military authorities, that is the fault of the House of Commons and of the party politicians, who are the curse of this country - who will not go to the IIouse of Commons and tell the truth and ask for the money that the country does not grudge. Neither the country nor the House of Commons erer grudges the money if the case be fairly put before them, and it is explained to them that the money is bond fide required for the defence of the country. But the party politicians ery "Peace, peace!" whero there is no peace-or at least where there are no guns. I saw the other day someono was kind cnough to suggest that as the original Armstrong field pieces were now wholly useless they might be turned orer to the Voluntecrs. I altigether protest against those guns being lianded orer to the Volunteers. If we erer meet any troops at all it will be, as Colonel Lonsdale Hale mell put it, the finest troops in Europe, and the finest artillery in Europe, and we ought to be giren the best guns that the richest country in the world can produce. At present the Tolunteer Artillery are armed with Sulder carbines. I think that is a mistake - Penny wise and pound foolish." Now, Sir, with regard to the subject of dress, which was the first point in the paper; many of Colonel IIarrison's suggestions for useful dress in time of war I think are exceedingly good, but I think it would be a fatal mistake to dress Voluntecrs in any drcss that could be distinguished at a great distance from the regular Army. It would expose them to rery great disadrantage. They cannot be too alike in general appearance to the regular Army. If there are good equipments, let them be giren to the regular Army and not to Voiuntecrs only. Then as to the question of funds. I formerly commanded the 1st Surroy Artillery, and I now command the City of London, and, therefore, I hare a double experience, and when I had the honour of being appointed to command the 1st Surrey I sent out a circular in the form of a beging letter to the Lord-Lieutenant, and all the magistrates, and crerybody me could think of or hear of. That circnlar produced $10 l$. When I was appointed to command the City of London I sent out a similar letter, and that, I am glad to say, produced a little more. The Ilerchant Taylors' Company and the Drapers' Company, I think, each gare us $10 l$. 10s. a year for prizes, and $I$ think somebody else gires us $5 l$. $5 s$. That is the extent of the assistance which the largest corps in the whole Mretropolis, comprising 16 batteries and 1,200 men, reccires from the richest city in the rorld. But I do not see why private persons should be expected to contribute to the national defence, and if $I$ seconded the amendment of Captain Price, R.X., the other day at Willis's Rooms, at a meeting whero it was proposed to get up a subscription fund for the Nary, it was beciuse I think it is the duty of party politicians to incur the odium of asking for the money which is necessary for the defence of the country. It would not take so very much for the Voluntecrs. Eren 10s. a jear might, perhaps, be sufficient, in addition to what we now leceire; certainly 15 s. or $-20 s$. would be sufficient. We ought to hare uniforms and a certain amount of equipment, grealcoat and gaiters given by the country. Is regards transport, $I$ think that might be left. in abegance, because in this country thero are so imany 
horses and so many vehicles of one bind and another for the limited area of the country, and so many bridges and milways and appliances of cirilization, that we do not require the same sort of equipment that is required by the Reserro forces in many other countries. I agree with Major Napier to a certain extent, but when he says that the 250,000 men are not arailable, I think he and Colonel Lonsdale Fale both forget that after all these men are enlisted and are bound to come out, at whaterer inconsenience, in caso of inrasion. But I certainly agree with Major Napier that such a corps as an artillers or rifle corps of the drsenal is an absurdity, because those men cmplojed in the Arsenal certainly could not go out in case of inrasion. There are sereral corps of the same kind that I think might bo use. fully suppressed, and the money now expended upon them sared to the country. Similarly-I am afraid Colonel Harrison may perhaps disagree with me there-I regard the Voluntecr Engineers as a waste of money. 'This country. Ias moro engineers, more contractors, more gangers, more narries, more fitters than all the rest of Europe put together, and if a railway bridge were suddenly to break dorn I fancy that a railway contractor would repair it more quickly than an Officer of the Royal Engineers. I really think these 10,000 military engineers in this country aro a waste of money. They are taught all kinds of military cngincering workmaking fortifications, pontoon bridges, and all that sort of thing; but such work as this, in my judgment, would not be required in this country in case of invasion, and therefore it is a waste of money. There are plenty of Engineer Officers and Stafl Officers who could direct the engineers, controctors, gangers, and narries to whom $I$ hare alluded, in the throwing up of anything resembling a permanent fortification, and for hasty work; the infintry and artillery might be trusted to make those protections for themselves. When Colonel Harrison says the Voluntecrs hare it in their power to proride themselres with personal equipment, I can assure him that is not so. He eridently is under the belief that a large proportion, if not the majority, of the Volunteers at the present day are composed of these rell-to-do middle classes who no doubt formed a large proportion of the first Volunteers. That certainly is not so in $\mathrm{my}$ own corps; it is a rery small proportion indeed of middle-class men who are in the ranks. The rast majority- 80 or 90 per cent.are artizans and shopmen-men whose arerage earnings I should think do not exceed a couple of pounds a reek, and therefore it is impossible to expect them, in addition to giving up their time, also to supplement the grant which the rich country whom they serre thinks enough for its soldiers. As regards the awount of drill that Voluntecrs go through - speaking again of my own corps-it is not an uncommon thing for a man to put in 100 drills in the year, and when you find that that man has done so for perhaps half-a-dozen ycars continuously, it is impossible to doubt that that man is an efficient soldier. This year, for instance, I went to Dorer with my corps, and took 616 men-a large number-some of whom were there for a week, some a day orer a week, and no oue less than three or four dajs. They carried out their garrison duties exactly as if they had belonged to the Rojal Artillery. With regard to Officers I agrec entirely with the statement that jou can hardly have Offeers too good for the auxiliary forces; but where are they to come from? We must do the best we can with the men we hare got; and although certainly some of my Oflicers are not just what I could wish, I hare others who are excecdingly good, and a certain portion hare passed through the School of Gunnery. I hare just tried the experiment of writing a memorandum for the information of the junior Offlecrs; to the effect that I would not again recommehd any Officer for promotion to the command of a battery who had not passed through the Scliool of Gunnery at Woolwich, and I am delighted to saj, so far from that being taken il!, it lhas been taken very well indeed. And when you consider that that gires a month's training to a certain extent in the theors, and still moire in the practice, of artillery, I think it is impossible to doubt that a man who has passed througl the School of Gunnery, and also has ecred some jears in camps of instruction and so forth, is reasonably fitted for his duty.

Colonel HowadD Frscext : The liour is late; and I should therefore only like to add my assurance to Colonel Harrison's, that no further assistance towards the Toluntecrs can be now obtained from the public than is obtained. I think there is hardly a Tolunteer Commanding Offeer who lias not already anticipated his 
suggestion that a general statement should be made to the inhabitants of a district in which their headquarters are situated. I mag mention it as a matter of fact I did so myself within a rery few weeks, and in response to fifteen letters of appeal to rery wealthy persons the net result was a subscription of five guineas. I am afraid that is not a rery encouraging thing to lead us to expect ansthing more. The title of this paper, for which I am sure Volunteer Ofliecrs are much obliged to Colonel Harrison, is "What can the Voluntecrs of Fingland do to render themselves fit to take the Field?" I would renture respectfully to say $I$ think they can do exceedingly little without further assistance on the part of the Government. The Gorernment at the present moment gives us no drill grounds, no rifle ranges, and although wo have facility, as far as funds are arailable, afforded us, still we cannot get on as we are at present. I can but express my indiridual hope, and I feel sure it is shared by many Officers here, that the Gorernment now in power may do what their predecessors did in 1878 , and grant a Departmental Commission of Inquiry into the needs of the Toluntecr forces.

Captain TODD: I think what we mant at the rery first outset, in order to assist the Tolunteer serrice to take the field, is not so much personal equipment, because we could go in any orercoats that the men had if it were necessary, but that we should most certainly not be fitted out with guns that are obsolete. We hare carbines, as you know, that are obsolete, whilst the infantry hare the Martini-Henry. Our men practise nearly three nights a week, each battery haring their own MIorris tubes fitted up in the drill sheds, and they do the best they can with their Snider carbines. How can they do more without the Gorernment assisting them by giring them the very best weapon invented, and providing them with ranges for practice? There are nearly a thousand efficients in our brigade, and I will undertake that any Royal Artillery Oflicer having seen those men at Shoeburyness or elsewhere, will say that they are fit to go anywhere and do anything if you only gire them the proper guns to do it with. I am sure the camp at Shocburyness will be found well worth a risit by Offecrs of erery branch of the regular Serrice, who hare made remarks with regard to the rant of discipline in the Foluntecr forces. There is not a man in our brigado who conld not bo put on the field to-morrow if they were properly equipped, and had proper guns to go with. We will not hare a paper man in the regiment. I hare not a single paper man in my battery, and I do not know a single brotlier Officer who has a paper man in his battery. But why is this tho present state of our corps? It is because we are sehoolmen. Wo go to Woolwich and to Shocburyness to study under the best masters and with the latest weapons for two montls. Wo aro not satisfied even with our own artillery studies and drill. We also go to the Guards for six weeks, and we go before the Board of Officers for our infantry certificate, and those who want to go into our mounted work with 10-pounders (ne hare no field batteries, our guns haring been taken array from us on the ground that we did not understand horses, and, as one of our opponents said, the Voluntecr Oficers could not ride a horse two dajs without a sore back) must also go to the Cariley School for their riding certificate. We must hare great self-denial to put up with what we hare done for the last twenty-six jears in the Polunteer forec, and for ny own part I beliere I am stronger in feeling in farour of the foreo now than I erer was in my life. We hare gone through good report and eril report, but no man cares for the evil report if he knows that he is right limself and hnows his work. But me feel this, that it is no use spending our raluable time, and we must spend a considerable amount of money, unless we are supported by the Gorernment of the country. I blame the public. I do not blame the military authorities one bit; they hare to look after their own branch of the Arms. We must hare certain expenses. But what $I$ say is that our regular Army, more particularly the mounted hranches, are not one-tenth of the number they ought to be ronsidering our largo possessions in all parts of the globe. I consider that the Volunteers must be trained properly, but of all things they must bo armed and practised with the rery best weapons in existence; they will bo able alono by proper. organization aud equipment to defead tho country without tho aid of a singlo regular except the Staff. Tho Volunteers were first started about twent5-six Jears ago. I know one case in which a publican was elected as offeer in a regiment, beause in those days an Ofleer wight be elected by a certain number of men if ho 
were a jolly good fellow, and was ready to spend any amount of moner, but the result was there was a great want of discipline. Now the Oflicers are a rery different class of men; Jou have men who go into the work for the lore of it, for their lore of country, as patriots, and will study thoroughly the arts and science of mar, and we have not got men with pipes in their moutlss, who march about the streets wanting in discipline and dressed half military and half cirilian. They hare been trained for years by their Oflicers and sergeant instructors from the best military schools of the country, and if there is any truth in the report of the Inspectors we certainly ought to be able to go anywhero and do anything, and if we are not, then wipe us. out of existence allogether. Do not have a paper man in the Scrrice. You talk about 250,000 men; why, we ought to hare millions of men. I beliere erery man in the United Fingdom should be prepared to defend his country, not by simply saying so, but by doing it. Any fellow can say, "I am prepared to go to-morrow to defend my country." He is simply an idiot, who rould only be in the ray. WV want fighting men-men who will study how to fight, and the scienco of war. It is something like a man who says, "Oh, I hare no need to learn the use of tho glores; should I be attacked I am strong, and can tackle any man." He finds his mistake out when he quarrels with and fights a man who is trained to their usc, by getting a thresling at the hands of a scientific boxer. We are simply learning to use the glores for eelf.defence, and learning the science of war, and we want to be supported in that. If you do not gire us the meapons to work with, what is the use of our going to the School of Gunnery, Infantry, \&c, and studying with all those improred brecch-and muzzle-loading guns of the newest patterns if me are not to hare the guns ourselves? This last jear we were serred out witl 20 -pounders for the reriew and sham fight at Bighton. Now when we get before the enemy the 20-pounder is an obsolete gun, and there is no shrapnel shell manufactured for it. We concluded at once that the Gorcrnment were going to gire us this gun for serrice against the enemy ; we must teach our men that there would be shrapnel shell, so we ordered them to fire as with shrapncl. We hare not these guns ; they mere lent for the day, and returned to Woolwich. What I rould say is this-nerer mind about greatcoats, because thcy can easily be obtained, but do let us be practised beforehand with field artillery, and gire our men the Yartini-Henry carbine. You cannot do without field artillery any more thon Jou can do without caralry; jou cannot figlt a battle without erery branch of the force being properly represented, but at the present moment we are actually without caralry and without field artillery, and when you say, as many people hare said, that not only are the Volunteers inefficient, but they are also useless, and that the Yeomanry Caralry are also useless and inefficient, it turns out after all that the reason is that their shooting irons are bad, and that they hare no ranges to practise upon. The Gorernment neglect their omn Irousehold Caralry, for the 1st Life Guards hare no ranges to shoot at. Can we therefore be. surprised at the Volunteer Army being neglected ? I cannot. imagine how it is that the public are such fools as not to agitate on the hustings and everywhere else that a proper force should be kept up in orler to defend the country, and that it should be prorided with the rery best reapons, and be in a state of tho best possible discipline, and ready to take the field without the slightest delay.

Colonel Lord RAxelagir: It is too late t 5 discuss any matters other than that which we haro really got beforo us, and what I shall say will be simply half a dozen words. In the first place, I am glad to take this opportunity of thauking Colonel IIarrison for his practical suggestions. In theso lectures we generally hear a rreat many complaints, but rery seldom any remeds. Colonel Harrison hos put before uz his practical ideas of the equipment of a soldier, and I agree with him in most of them. We hare already heard an allusion to the top-hat: I think that is a mistake; the Glengarry cap is a soft cap and rery much more comfortable to sleep in. The only thing I was going to say is this: I am constantly bearing of the painful state in which wo are with regard to the organization of the Army. ITrenty-two or twenty-three jears ago I wrote a letter stating that the Yoluntecr force was a sham. That letter was taken most ungenerously, and I was abused in crery direction. What $I$ said was fact, and $I$ say it again.now. The Volunteer force is as fine a force as any body in Europe, -there is not:a finer body of men nor 
men more amenable to control, but that is all jou hare got. You hare no organization. I say it is a disgrace to this country that we hare not got into a state of organization, so that we can put our hand upon these 250,000 men and march them I won't say in twenty-four hours, but in a rery short time, to any part of this country. I will now offer a practical suggestion, which perhaps some gentlemen will think of some day. Wo lave on the diagram before us a statement that there are 50,000 agricultural horses in England, and altogether 70,000 horses that might be arailable at any moment. All that is necessary is that they should be organized, and $I$ know of no man more fitted to undertake that task than my friend in the chair. I can see no difficulty in making your Lords-Lientenant of counties a kind of district basis for this purpose. There you might have erergthing prepared for the central Staff. Erery county should hare at the oflice of the Lord-Lieutenant an account of the horses and men there, and in that way you might, in course of time, be crabled to get an estimato of your forces, and hopo to mass jour men together.

Admiral Bors : Although I am an Admiral in the Nars, I think I may claim the pririlege of offering a few remarks, as I am probably the oldest Voluntec Offece in this room. I was one of those who gare their time and energies to the organization of the Volunteer force in the Jear 1860 . In those dajs, we gare our services, and we gare our money, wo lad to pay for crerything. It was owing to the Report of the Rojal Commission that sat in 1862 that the present capitation grant was giren by the Gorernment. I do not quite arree with what Colonel Lonsdale Halo has said that at the commencement of the morement we gare our serrices as serrants to our master, and that as we got morc raluable we demanded more and more wages. The fast was simply this, I mas instance the corps to which I belonged as a rcpresentative one. It was a small country one, fairly drilled and disciplined. We paid for erergthing ourselves by raising all the subscriptions from the neighbourhood that we could, and wo went on rery well for two or three years, but then the money dropped off, and we positirely could not get on without more assistance. Irad it not been for this capitation grant, tho efficient battery of artillery Volunteers to which I refer, and which I beliere exists now, would hare died out altogether. I cannot myself agree that the Volunteers can get on without an increased capitation grant. Many hundreds and thousands giro their time, and they hare not got mones to gire. I do not understand the argument of the Oficer who said that many Volunteers if they were called out would gire notice of learing their corps, because they had certain business occupations. In my day I know there ras an Act of Parliament by which, when the Yolunteer was ealled out, there was no seren or fourteen days' notice, he simply must go, or be would be a deserter.

The Cmairurax: That is the case now.

Admiral Bors: I do not think under any circumstances the Volunters would gire notice when called out for serrice; their comrades would despise them if they did so. I haro only ono more remark to make, and that is with referencs to raising subscriptions for the defenco of our ports by purchasing torpedo-boats. I heard part of the debate to which referenee has been made by Colonel IIope; he seconded an amendment, and $I$ held up my hand in its farour. I believe it would bo an absurdity to ask the country to subscribe to purchase torpedo-boats for the defence of our lome ports. In tho first place, the torpedo-boat is not the best defenee for a mercantile port; and in the next place, I beliere, in no caso should the public be called upon to subscribe for the naterial for this purpose. I quite beliere that if the wants of the Serrices, the drmy, Nary, and Volunteers, are properly put before the House of Commons, and before the public, they will authorize the Goremment to expend any amount of money to provide the necessary defences of the country. I perfectly anrce in raising public subscription to add to the efficiency of the Voluntcers in personal equipment and other necessary expenses, but I am strongly of opinion they require a great deal more assistance from the Gorernment thas they get at present.

Lieutenant-Colonel Rovtredge : I am sure erery one hero must have listened to the lecture rith rery great pleasure; as far as I am able to judge the equipment shown to $u s$ is the rery best and most easily carried that I have erer seen; and the suggestion that the kit bags should be carried in carts is a rery good onc. I take this opportunity' of protesting rery strongly about the way in which the Volun- 
teers hare been spoken of by one or two Oficers. I don't doubt that Colonel Lonsdale Hale and Major Napier were simply saying what they thought, but at the came time I think they rery greatly under-estimated the ralue of the Voluntecrs. We know that we have 250,000 Yolunteers on paper. Out of these 250,000 probably something like $2 \$ 0,000$ hare been eeen by inspecting. Officers, and the inspecting Officers' reports in most cases are that they are an efficient body of men. Major Napier sass we should get no men out at all if we wanted them; now I hare it on the best authority from an Officer of the highest rank, who feels sure that if the Wur Ofice were to call on Volunteers to roluntecr for actire serrice anywhere, it would get at least $30,000 \mathrm{men}$, at a rerg few days' notice. As to their not coming nut in case of inrasion, they would hare to come, the Toluntecr Act prorides for that, and as one spenker very properly said thoso Volunteers who did not come forward when called upon would be scouted by their comrades and friends. There is one more question: Colonel IFarrison says that the Folunteers ought to equip themselres at their omn experise. This demand is not reasorable; ro hare dono as much as we possibly can do, we have learned drill, discipline, and the use of our arms, but I am sure without the assistance of the Gorernment we could not go beyond that. The well-to-do Volunteer, the man who is able to put his hands in his pocket and draw out his money and pay for erersthing himself, does not exist except in (wro or three battalions, and no subscriplions can now be got from the publie. That source is exhausted. I beliere some of the City Companies gire liandsome donations erery year to some of the City regiments, but I do not think that they are disposed to go any further than that. We have done what we are nble to do, and we are willing to do a little more if called upon to do zo. The Volunteers go in large numbers with corps at Aldershot, Shoeburjness, Woolwich, and elserrhere. I am strongly in farour of their going to those camps rather than going to regimental camps, I think much more is learned from them, especially as regards discipline; it really comes to this, if wo aro rorth liaring we must be further supported by the Gorernment. Colonel Hale said that if you are prepared to spend $10 s, 11 \frac{s}{5} d$. on an article you would not grudge an extra farthing if necessary to secure it. If we are to go on improving, are to be made more fit to take the ficld than we are now, we must go to the authoritics and ask them to gire us the extra money that wo require. Let them satisfy themselres that it is spent properly, but anything more to be done must be done by Gorernment. We will gire more time, we cannot gire more noney. If the Secretary of State for War chooscs to ast the House of Commons for an additional grant for the Toluntecrs to render them effectire, and can make good his case, I am quite certain no House of Commons will refuse that grant. We are all deeply indebted to Colonel Harrison for the rery interesting and instructire lecture he has read to us.

Captain Mlexps: As an Adjutant of four years' standing in the Voluntecrs I think, perhaps, I might be permitted to say a word on this subject. It seems to me that the discussion has tended greatly to matters of detail; after all the principal object of a soldier is that when he gets into the field he should be able to use his arms. $M Y$ experience of Volunteers quite agrees with that of Colonel Hale and Major Napier, that they are at present absolutely unfit in that respect. They may appear very well at inspection, they may march past fairly well and perform two or thrce battalion nancurres indifferently, but the shooting is not considered in the inspection. The corps of which $I$ an Adjutant bas the reputation of being one of the best shooting corps certainly in the Mretropolis if not in the country, but our figure of merit last year was considerably below the third class shots. We are a rery strong corps, and. I am really ashamed to say what the figure was, but it would hare been disgraceful in any regiment of the line. It is all rery well providing greatcoats and water-bottles and all that, but those are things that can be prorided at rery short notice. You cannot teach men to shoot under two or three months. It is not only shooting at a target, it is shooting at a small and practically invisible object. We all know that in sporting you cannot learn to shoot at a bird at a short distance that jou can see pluinly without a considerable expenditure of ammunition and time: much less can a man bo tuught to shoot in the field rithout training. Moro monez is ranted for the Tolunteers, but their first and main duty would be to expend it in teaching the men to shoot. But to teach sbooting requires time. You want more than an Adiutant and two or three sergeant instructors for a lorgo 


\section{'THEISELVES FIT TO TAKE THE FIFLD?'}

1111

number of men, and jou must compensate the men themselres for their loss of wages. Thero are a for men in erery regiment who giro up an enormous amount of time to shooting, but they are mostly commercial trarellers or men whose time is. pretty much at their own disposal; the great majority of men who haro fired hours, clerks, artizans, and others, cannot go down to the range. I hare tried the: experiment of shooting through erery one of my recruits myself, but $I$ found that though I could fix my own time to go to Harrow the men often disappointed me, they could not come, not that they would not, but they really could not get away; and then when they found they could make a rush off some crening they went when I was not there: Therefore I think instead of all the detail, the equipment, and perhaps the headquarters of which a great deal is thought; that if more thought was giren to ranges and giring money to compensate men for the timo they lose by going to the ranges, and to getting additional instruction for the men when they do go to the range, it rould add rery much moro to the efleiency of the force. IIen may be perfectly equipped, you may hare magnificent headquarters, and the men may be fairly drilled, and yet when they are sent into the field if we find that they cannot sloot they are worse than an incumbrance:

The Cralusax: I think it is now time that we brought this discussion to a close: Fou will all agree with me that Colonel Harrison has read a rery raluable paper; he has eridently giren rery great attention to the subject, and is a master of it. I therefore hope that when the time comes for completing the equipment of the Yolunteers-and the sooner it comes the better-his viens will not be lost sight of. Colonel Irarrison in his paper made a remark well worthy of attention: he said that, without calling for a siugle penny from taxpayers' pockets, it is possible to add rers considerably to the effeiency of the Yolunteer forces. Of course, that must be done by improrement in organization, and the remark extends, in my opinion, to the other military forces of the Cromn, as well as to the Volunteers. When, lowerer, we come to equipment the case is different; then we must hare an increased expenditure, and $I$ am in justice bound to say that Colonel Irarrison has not shirked that subject. It is one of great difficulty, because when you increase the equipment of the Voluntecrs the question arises at once who is to pay? Colonel IIarrison, as I understand him, would hare each corps in its own locality canrass tho public for an increase of funds. Now those of us who hare been connected with the Volunteer force know that that expedient has becn many times tried, and generally found wanting. It is true that Colonel Harrison adds that there should bo a Central Association, which would aid the separate corps in raising the funds that may be required; but, for my part, I do not see how a Centrel Association could gire any assistance to individual corps in such a measure unless by proriding funds itself, and I do not suppose that it could undertake that. It has been remarked in the paper that in the early days of the morement it was an idea very prevalent that the Folunteer should not only gire gratuitous serrices to the country, but should also provide himself with what would be neccssary for carrying on his duties properly as a soldier. If I mas use such an expression, that was in the heroic period of the morement. Since then more prosaic viers hare conc into the ascendant. It is now, I think, tho ruling idea that if a man gratuitously gires his services to the country in time of pence to learn his duty 23 a soldier with the contingent privilege that in time of mar his life may be taken in the defence of his countrs, he is entitled to call upon the Gorernment to proride him with whatsoeres mar be necessary in the shape of personal equipment for carrying gn his duty as a soldier properly. I think that this states in a few words exactly what the position is, and I must say I gire $\mathrm{my}$ adherence without hesitation to that riew. Tho Gorernment of the country has now a Volunteer force of 250,000 men, and not. vithstanding the pessimaistic riews which hare been expressed this afternoon as to the state of that force, I ama quite prepared to say (and I know a little of the force) that for the defence of this country it is of great value. When we say that the British Empire extends orer territory on which the sun nerer sets, wo by no means use a figure of speech, we gire expression to a simple geographical fact, of the truth of which any man can conrince himself by taking a tẹrestrial globe. Let hiin turn it round as he pleases, and his eje will nerer lose sight of British Possessions. Now when we come to provide a force to defend those rast Possessions, I think we fall very far short of the mark, and the consequence is that our regular Army is almays 
working at high pressure, carrying on hostilities in distant lands with a mero peace cstablishment. That is rery lard upon our soldiers, and in many cases it leads to disastrous results; but would not the case be infinitely worse if the country had not a Foluntecr force to fall back upon for the defence of its own shores? I think it would : therefore the Gorernment is bound to proride erergthing that is necessary to make the Volunteers efficicnt. The principle of Gorcrnment aid was conceded when the Ierislature authorized the War Oflice to gire a capitation allowance to the Voluntecrs, and now the question is mercly what the amount of the grant should be. I sar, in the name of common sense, that if the capitation grant is giren at all, make it adequate to the purposes for which it is intended. So much for the question of equipment. Then with regard to the other point which Colonel IIarrison takes up-and that in a rery able manner-namely, instruction in military dutics, I quite agree with him, that it would bo a good thing if a manual were drawn up for the instruction of the Yolunteers. Ho has giren an outline of what such a manual should contain, and I hare only one suggestion to add, which is this, that Colonel Irarrison should himself undertake the duty of compiling that manual, for I am quite sure it could not be confided to better hands. Time will not permit mo to follow all the criticisms that hare been offered upon tho paper, and also upon subjects somewhat irrelerant to it, but there is one exception I must make, and that is as to what has fallen from my friend Colonel Lonsdale Hale. Whaterer he writes, or speaks, I know, from a long acquaintance with him, deserres the most serious attention, but I think he has rather unduly underrated the ralue of the Voluntecrs. Probably if he knew more of them he would entertain a bigher opinion of them: But he has made a suggestion which to my mind is well worthy of consideration; whether it would not be possible to make what I may call some elegant extracts from tho Tolunteer force in the shape of men who have more time than their comrades to derote to military instruction, and to going into camps for a certain time crery jear. I am quite certain that men who would undertake such work as that would soon become rery raluable soldiers, and would be fit for their duties carlier than the rest of the Volunteer force. I will not detain you longer. I take for granted that you will unanimously commission me, as your Chairman, to offer our best thanks to Colonel Harrison for giving us the benefit of his studies on a subject both important and interesting.

Colonel Marnisox, in reply, said: I must thank you, Sir, very much, and also those gentlemen who hare spoken, for tho way in which they hare receired the fer remarks that I hare offered to-day. I hare ouly two or threc points in the discussion to allude to. When I incidentally referred to a " hat," I carefully abstained from indicating what pattern that hat should be. But I may say that such a hat: as I recommended, besides being exceedingly liandsome, was used by hundreds of thousands of proctical soldiers in the American War. With referenee to "doing away with the Tolunteer Engineers," I cannot allow that assertion to pass without a remark. I had thought that in these days of submarine mining, telegraphs, railrays, and tho rarious scientific appliances used in modern war, engineers were coming even more to the front than they lad done in the past. At all erents, the bistory of the railway from Suakin to Berber ought to disposo of any such assertion as the one I allude to; for, if the reports bo true, the contractors men failed in making that railway, and could not get on at all without the Mititary Engineers. With reference to the question of "money," I must remind the meeting that I said that if the money could not be got from the country, as was donc in former years, it must be got from the Gorernment. But what I adrocated was getting it in the slape of a grant, and not of equipment, because $I$ am sure that the Volunteers, if left to themselves, will provide themselves with a really good and useful equipment, more suited to their needs than one that might be supplicd by the Gorernment. Just one thing more and I hare done. From Colonel Daris's remarks I gather that what I said about drill was misundcrstood. When $I$ said that certain drilis were not required for the Voluntecrs, I did not mean that they did not want drill, I meant that tho description of drill should be most carefully considered; and that they should not be taught one iota more than was absolutely necessary. For instance, I do not see the good of their spending hours and hours on euch drill as "goose-step" and "cxtension motions." With these few remarks I beg to thank one and all for the kind attention giren to my paper. 